\title{
THE CAVE EXPLORATION GROUP OF EAST AFRICA AND VOLCANIC CAVES IN KENYA
}

\author{
Michael Declan Kennedy
}

\begin{abstract}
This paper looks at the history of the Cave Exploration Group of East Africa with special reference to the exploration of volcanic caves. It demonstrates that the group has concentrated on two main areas, the Chyulu Hills and Mt. Suswa, although other areas have also been studied. The Cave Exploration Group of East Africa has had to cope with various problems. The most important of which are related to the socio-economic conditions of a developing country. These problems have not prevented the group from making a valuable contribution to vulcanospeleology.
\end{abstract}

Keywords: Caving Club, vulcanospeleology, Kenya

\section{FORMATION OF THE CAVE EXPLORATION GROUP OF EAST AFRICA}

The history of cave exploration in Kenya goes back at least 5,000 years. Dr. L.S.B. Leakey found evidence of human habitation at Gamble's Cave at Elmentaita. This dated from the Upper Kenya Capsian period (5,000-10,000 b.p.) (Clarke, 1996). Various Kenyan communities used caves as refuges, burial centres, for minerals and as religious centres (Mwaniki, 1973). The first published account of caves in Kenya is Joseph Thomson's account of the Mt. Elgon caves, although he mistakenly decided that these were formed by an ancient superior civilization mining for "precious stones or possible some precious metal" (Thomson, 1885). The caves are formed by water erosion in soluble pyroclastics, but have been extended by mining (Bristow, 1961).

Although the Cave Exploration Group of East Africa was formed during April and May 1964, its origins lie slightly earlier. Dr. P.E. Glover, of the Dept. of Veterinary Service and Dr. Guest, of the Mines and Geological Dept., accompanied by their families, paid a visit to Mt. Suswa. They were guided by Mr. D. Hobden, also of the Mines and Geological Dept., who had been carrying out geothermal investigations in the area. Dr. Glover had noticed holes in the lava flow on Mt. Suswa from the air, but had not been able to get access to them until Mr. Hobden had made a track up the mountain. The weekend visit confirmed Dr. Glover's suspicions that these holes gave access to lava tubes (Glover, 1965).

Dr. Glover found evidence that primitive man had visited the caves. This took the form of obsidian artefacts and stone tools. The local Maasai confirmed that the caves had been visited by Wandorobo (now more commonly called Okiek) hunter gatherers. The caves were used during the Emergency (1952-60) by Mau Mau freedom fighters as refuges. The Maasai themselves were reluctant to venture beyond the day-lit entrances of the caves (Glover, 1965). Dr. Glover began a scientific study of the caves. In company with other interested parties, he began the initial mapping of the area and began to survey caves. Studies were also carried out on the geology and ecology of the area.

\footnotetext{
* Librarian, Cave Exploration Group of East Africa - P.O. Box 47363 - Nairobi, Kenya.
} 
Mr. Hobden's road gave easier access to the lava flows and the number of visitors increased. Many of these visitors came for scientific studies, but others did not share their respect for caves. Specimens were damaged and artefacts, including bones, were removed. To protect the Mt. Suswa caves, a conference was held during April and May 1964 amongst interested parties with a view to conserving the caves and to encourage their scientific exploration. These conferences took place at the National Museum of Kenya and resulted in the formation of the Cave Exploration Group of East Africa, with Dr. Glover as the first president of the Society.

\section{CAVING AREAS}

During the first year and a half of the existence of the Cave Exploration Group of East Africa, Mt. Suswa was the main area of exploration. Forty per cent of all caving trips were to Mt. Suswa. These expeditions concentrated on surveying known caves, searching for new caves, the geological structure of the caves and the fauna and flora of the caves and the surrounding area. This seeming overconcentration on one area is justified in that it is one of the most complicated areas of lava tubes in the world. In 1971, four new caves were discovered on Suswa (Davis, 1971a, King, 1971). Indeed in 1973 a whole new area of lava tubes was discovered and explored by Arkle, Davis, Mason, Shuttleworth and Simons. This was near the moat and a good distance from navigable roads. A new tube entrance was found about $200 \mathrm{~m}$ from the well visited entrance, Collapse 12. Other areas visited in this period included Mt. Elgon and the rediscovery of the Cave of God (Ngumut Ngai in the Maasai language, Maa), which was described by Gregory in his account of his journey through the Rift Valley (Simons, 1969). Simons identified 39 known caves or collapses with the potential for extension via digging or pushing (Simons, 1979). The sheer number of tubes in the lava flow and the complicated arrangement makes it well worthy of study. In the main cave area there are 69 known entrances with some 40 cave series totally over $11 \mathrm{~km}$ of passage (Simons, 1998).

As the Cave Exploration Group of East Africa gained new information more cave areas were added to our knowledge. Erosional caves in the Kiambu and Thika regions were explored. These caves were popular as they close to Nairobi and quite sporting. The badlands area around Mt. Eburru and the Rift Valley north of Nakuru were also popular (Davis, 1971b). Small caves were also explored on the Delamere Estate near Lake Elmentaita. This period also saw the initial exploration of the Chyulu Hills that was to become a major focus of future study.

The Chyulu Hills area was known to have caves. Shaitani Cave had been fitted with ladders to allow tourists to the Mzima Springs camps to visit about $200 \mathrm{~m}$ of passage. In 1969 new passages were found in the area running from collapse holes (Simons, 1971). The Chyulu's, being a comparatively young chain, had many areas of fresh lava flows. These had every indication of cave bearing potential. The North Chyulu area has many fine tubes, some of which appear to be part of a blocked linear tube (Simons, 1972b). The Mathioni Cave was mined for bat guano and opened as a show cave (Simons, 1972c). Other caves and trenches are found all along the Chyulu's, but there has been little exploration of the Western side of the range. Currently ninety different cave structures have been located in the Chyulu's (Simons, 1998).

In 1974 CEGEA had a major change of direction. Aerial photos had shown what appeared to be more entrance holes in the Chyulu Hills, in a lava flow running down to the Kibwezi area. Upon investigation the following year - they went. The first reports 
indicated a half kilometre of tube on either side of the entrance. This gradually got longer and longer on each visit. It was announced that Leviathan existed (Simons, 1976). This was like a drug. Every other two weeks there was a trip to extend this monster. We were going to get the longest lava tube in the world. The thing was immense and it had levels that seemed to breed new levels. Hard core members such as Dave Womack and John Arkle gave up weekends of their lives moving the maypole, digging, pushing and surveying to do justice to one of the greatest underground systems known to human kind. We ended up with over twelve kilometres of cave and are still digging at the Top Choke in hope of extending it further. Leviathan saw the most intensive effort ever on the part of the Cave Exploration Group of East Africa when 19 people descended on the site from the 10th to the 19th April 1976 to survey the monster. The first transit was made in 1985. This involved teams on the surface waiting to service the underground team. To everyone's surprise the underground team made much better progress than the support team which had to batter its way across the bush to various entrances. Several other caves, such as ABC and Pango ya Moshi (Smoke Cave) were found in the vicinity of Leviathan, but were found to be separate systems. There was a decline in activity in Leviathan during the late 1970's and early 1980's. The newsletter expresses surprise at this, but in retrospect it can be explained in economic terms. In the early 1970's Kenya went through recession caused by the effects of the oil price shock after the Yom Kippur war of 1973. Between 1976 and 1978 there was the 'coffee boom'. The economic chaos in Uganda under Idi Amin Dada led to massive smuggling of Ugandan coffee through Kenya. This coincided with a world coffee shortage and consequent high prices. The ouster of Amin and the decline of coffee prices in the face of the world recession after the second OPEC price hike of 1979 hit the Kenyan economy badly. Cavers could not afford the long travel needed to spend a weekend at Leviathan and they tended to concentrate on the nearer Mt. Suswa.

As the economy began to recover there were massive efforts to study and survey the upper levels. The Cave Exploration Group of East Africa logbook is full of entries that say "moved the maypole". Currently Leviathan stands at $14 \mathrm{~km}$ of surveyed passage, with digging continuing at the Top Choke in hope of finding an extension. Even when we were gripped with excitement about Leviathan visits were still made to our old haunts. In 1976 Mathioni was extended by another 100m via a crawl which had been attempted but not pushed before. John Arkle pushed cave 12 on Mt. Suswa as well as spending a lot of time and effort on Leviathan. His efforts made 12 the longest system on Mt. Suswa, which was an added bonus, as it was one of the most interesting caves with some of the most magnificent flow patterns we had seen. In 1977 Simons and Timberlake found a new tube of about $100 \mathrm{~m}$ length leading out from the first collapse in the lava flow. Further discoveries were made in 1984. This find shows the potential of even such a widely visited area as Mt. Suswa to yield new finds. Naturally the logbook shows the shift in emphasis from Suswa to Leviathan. While there were nearly as many trips to Mt. Suswa as before, in terms of days spent in caves Leviathan was far ahead. The effort to push and survey Leviathan led to a neglect of surveying in other known caves. As a result some of the caves on Mt. Suswa have not been properly surveyed to date.

Mt. Elgon has always been a major attraction. This necessitated a four or more day expedition, due to the distance from Nairobi. While there were members elsewhere, especially Nakuru, they had to join up with the majority from Nairobi to make a worthwhile party. While local farmers knew of the cave entrances, and in many cases had explored them, and poachers certainly knew of them and used them as hideouts, CEGEA was the first group to seriously survey such caves as Kitum and Hampton 
Court. The latter was a particular favourite as a testing ground for novice cavers. Its maze-like nature made it a hilarious examination of navigation and surveying skills (Davis, 1972). In January 1980 Kitum cave was identified as a primary vector in a suspected case of Marburg Virus (Preston, 1995). Cave Exploration Group of East Africa members co-operated with the Centres for Disease Control and the Kenya Medical Research Laboratories in donating blood samples for analysis and guiding research parties to the cave. CEGEA members showed no traces of the virus although they were frequent visitors to the cave. Indeed CEGEA members wore ordinary caving gear while leading the researchers dressed in full biological protection suits into the cave. Nevertheless, many members were reluctant to venture onto Mt. Elgon for some time, there being no trips between 1981 and 1989 .

Mt. Elgon was never as widely visited as the Chyulu Hills and Mt. Suswa. The distance meant that a long weekend, such as Christmas, Easter or one of our public holidays, was needed to gain enough free time to reach the caves. Other interests such as Leviathan, Silali and combining the limestone of the Coast with a weekend on the beach also contested this time.

The new area of study seems to be Mt. Silali. This is at the border of Baringo and Turkana districts and was reported to us by geologists doing geothermal surveys for the Government of Kenya and the Overseas Development Association. The main tube that has been entered here almost defies description. It has the potential to surpass Leviathan. The exploration of Mt. Silali has been intermittent. This is due partly to periods of insecurity. The distance and inaccessibility means that a five-day expedition will yield one day of caving with the risk of either not reaching the cave or being cut off for some time by the sudden and unpredictable rains which flood the rivers and luggas (dry river beds). There are other potential cave areas in Kenya. The Yatta Plateau, a 300km long lava flow appears to have entrance holes when seen from the air. This plateau appears to have been formed from lava flowing down a river valley, the sides of which subsequently eroded leaving the plateau standing alone (Nyamweru, 1980). There are known to be caves in lava in Turkana district. Again this area is very far from Nairobi and the harsh climate is a further barrier to successful exploration.

As the Cave Exploration Group of East Africa we have also been active in our neighbouring countries. Expeditions have gone to Tanzania, although mainly to limestone areas. Clive Ward has found some fascinating tubes on Kilimanjaro and Arkle investigated blisters on Mt. Meru. Jim Simons has also investigated a lava tube on Mt. Nyamulagira in the Democratic Republic of Congo (then Zaire) in 1972 (Simons, 1972a). Mt. Nyamulagira erupted the following year but it has not been possible to return for further investigation. The continuing insecurity rules out a visit for some time. We have members in Uganda although we have not had much news. Somalia has limestone caves but we have not heard of any caving activity from there for a while.

\section{CAVING ACTIVITIES}

Cave conservation was one of the reasons why the Cave Exploration Group of East Africa was formed. CEGEA continues to exercise this policy. The Mt. Elgon caves are well known and attract a number of tourists who have seen wildlife films on the elephants in the caves. Other caves are less well known but are also visited by nonCEGEA members. Cave 18 on Mt. Suswa was used during the making of the film Sheena Queen of the Jungle. After the film crew departed, CEGEA members removed the debris that they had left behind. Crystal Cave on Mt. Suswa has extremely delicate 
and beautiful speleothems. The location of this cave has not been revealed to prevent unnecessary damage to the formations. CEGEA members have not visited the cave since its initial survey (Simons, 1974).

Like many other caving groups of this period the Cave Exploration Group of East Africa made much of its equipment, such as ladders from nylon rope and podo wood for the rungs (Mason, 1965). There was an extra incentive in Kenya. The government promoted a policy of import substitution to encourage the growth of local industry and to reduce its dependence on the export of primary agricultural products (Ogonda, 1994). This policy severely limited the amount of foreign exchange available for the import of luxury items, of which caving equipment was considered an example. As well as making its own equipment, the Cave Exploration Group of East Africa members resorted to various subterfuges of differing degrees of legality to obtain equipment from overseas. One favoured method was to persuade visitors to bring in equipment; another was to request visiting cavers to donate some of their equipment when they left.

Over the years the Cave Exploration Group of East Africa has often expressed doubts about its direction and viability, "We are still alive". This is because we go through periods where members leave and are not replaced, or when the existing membership seems to lapse into a state of inactivity. These periods are then followed by expressions like "well, we actually had a good year with lots of trips" or the infusion of new members. The areas of study also represent the interests of the membership.

Part of our worry has come about because of the changing socio-economic climate in Kenya. Most members cannot afford to spend as much time caving as they did in the 1960 's because they cannot afford it financially. As well as the general expense of caving, there is also the expense of running repairs on vehicles caused by the damage inflicted by getting to the caves. In Kenya the biggest potholes are the obstacles to be overcome before you even get to a cave. Although the extent of sealed and graded roads has greatly increased since independence it still does not reach the major caving areas. For example the amount of tarmac had increased from around 2000 to 9000 kilometres between 1964 and 1989 (Central Bank of Kenya, 1981). The economic problems caused by the effects of world recession, climatic problems and IMF-World Bank Structural Adjustment Programs have led to a slow-down in this expansion (Government of Kenya, 1996). Lack of resources for maintenance has caused deterioration in the existing transport infrastructure. By 1988 only $34 \%$ of the paved roads were in "good condition" (World Bank, 1995). The unprecedented rains linked to the 1997-8 El Niño phenomenon have worsened the state of the roads. The dangerous state of the road network in Kenya contributed to a serious accident in 1986. Jim Simons and Bill Tanner were seriously injured in a head-on collision with a vehicle attempting to overtake a slow-moving vehicle. They had to be evacuated to Nairobi by the Flying Doctor service.

In the early days of the Cave Exploration Group of East Africa we used to have many active members from the university and government departments such as geology. These members were able to combine their professional interests and research with their caving. Today we have very few such members. Civil service and university salaries are so low that most lecturers spend their spare time on paid consultancies in order to make ends meet. The Ndegwa Commission of 1967 that permitted civil servants to engage in business while still performing their government duties encouraged this policy. This policy permitted the government to give small pay increments while encouraging civil servants to find other sources of income generation (Leys, 1994). They have little time for other activities. This is one of the sad facts of life involving caving in a developing country.

A related problem is specific to Kenya. This is product of the local education system. 
Before Independence the colonial government employed Africans only in the lower levels of the civil service. Appointments were determined by educational attainment. At Independence education was reinforced as the key to advancement due to the Africanisation of the civil service. As a result a lot of stress was spent on passing exams (Berman 1990). Once exams had been passed and a position obtained then there was no further incentive to read any further to keep up to date in one's chosen subject or to pursue any research which did not bring any obvious financial benefit (Chakava, 196). This attitude has helped to hinder the spread of caving beyond a wider section of the populace. Sheer poverty is a further hindrance to widening the popularity of caving. A nation with a per capita income of under US\$ 300 will see caving as a luxury when basic needs are not yet met.

Specific problems in Kenya are tribal clashes and rustling. Rustling has been a traditional part of pastoralist life since time immemorial as different communities have myths in which God gave all the cattle in the world to them. Rustling was always carried out with an element of cultural ritual, discipline and traditional weaponry. The insecurity in neighbouring states led to an influx of modern weapons such as the AK 47 and rustling has turned into clashes between heavily armed bands (Karimi and Ochieng, 1980). During the 1992-3 period it was not safe to go to Mt. Elgon, due to clashes in that area, apparently generated by political tensions during and after the transition to multi-party politics (Troup and Hornsby, 1998). This area is safe now. Mt. Silali on the Pokot-Turkana border was also ruled out for some time due to rustling.

We have also come across caves being used by poachers, especially in the Chyulu's and Mt. Elgon area but luckily have had little trouble with them. It has been impossible to ignore their effects. The wildlife in these areas is much less prolific than when we first started visiting these areas, as can be seen by comparing entries in the Logbook from the 1960's and 1970's with more recent entries. We have, however, had some problems of access to caves. This is a universal phenomenon but has specific local ingredients. In 1974 a visit to a cave in the Nyambeni Hills that was used for circumcision ceremonies by the Meru people led to arguments about payment to the locals. The guide showing us the cave solved this problem. As an elder his words settled the matter. The Mt. Suswa caves lie on a Maasai group ranch and we have at times been asked to pay for access. We have not felt that this was justified as the local community has done nothing to help to maintain the access and the route up has continued to deteriorate.

Theft from vehicles while a caving party is underground seems to be a universal problem for cavers. This has necessitated the use of camp guards who are left behind to take care of the vehicles and equipment at all sites. There have been problems with security on Mt. Suswa. In 1974 a vehicle was broken into and camera equipment taken. The cavers who had suffered the loss had noticed two Maasai herdsboys who had been watching them earlier but who were now at a far distance, and who would not come closer when called. The two intrepid cavers took one of the cows from the herd and took it to a local police post. The police were able to prevail upon the Maasai to return the camera equipment in exchange for their cow (CEGEA Newsletter, March 1974). This was shrewd psychology on the part of the cavers as the cow is wealth to the Maasai. It also indicates the transitional nature of Kenyan society. The traditional respect for the cow as source of wealth co-exists with the knowledge of the monetary value which the camera equipment could obtain. The equipment would probably have been sold and the money gained used to buy more livestock.

Generally we have been more fortunate in our relationships with the local population. On Mt. Suswa Mzee Sulatun has been a great help to us in passing on information about the location of entrances (Womack, 1998). On the Chyulu's Julius Ngeka Kyule was also a great help as were many of his neighbours who found it fascinating that out- 
siders would be interested in their local holes and would even wish to enter them. This assistance is reflected in the came given to one tube Twende Mwende ("Let's go Mwende"), named after the young girl, Mwende, who told us about the entrance and after the invitation Twende Mwende, actually led us there. These local people have now been moved away to preserve the Chyulu Hills Nature Reserve as a National Park. This has led to tracks becoming overgrown and the vegetation to bloom with the absence of grazing animals. This has made access to some of the caves more difficult and much time has to be spent hacking (or thrutching in Cave Exploration Group of East Africa speak) through the bush to reach the cave. A lot of time is also spent looking for cave entrances, as the landscape can often be quite unrecognisable with a profusion of bush. The Kenya Wildlife Service now in charge of the Park has been very co-operative. They have waived camp entrance fees for caving expeditions and have also granted us permission to camp outside the designated campsites to allow us to be nearer the caves.

The Cave Exploration Group of East Africa has also maintained relationships with other sections of society. Thus we have led tours for members of other societies, such as the Geological Society, East African Wildlife Society amongst others to the cave areas of Mt. Suswa. We also have cordial relationships with the Mountain Club of Kenya of which many of our members are also members. Joint weekends have been quite useful. Visiting cavers and other interested parties have also been welcomed. For instance, in 1974, Dr. Bill Halliday paid us one of his many visits and discussed the possibility of holding the symposium in Nairobi (Halliday 1975). Visitors from the Society of Lancaster University Graduate Speleologists helped us push a new section in Leviathan, which was named S.L.U.G.S. in their honour. At this time we also received an offer of assistance from CROSA (The Cave Research Organisation of South Africa) in our exploration of the then newly discovered Leviathan (CEGEA Newsletter Jan-April 1977 p.7). Unfortunately this offer could not be taken up due to the political situation at the time. South Africa was boycotted by the member states of the Organisation of African Unity and South African citizens were not allowed to enter Kenya (Orwa, 1994). The politics of the nation also affected us in a small way. When Kenya gained its independence in December 1963, Mzee Kenyatta was Prime Minister with a GovernorGeneral representing the Queen as head of state. In December 1964 Kenya became a republic with Mzee Kenyatta as president. Out of respect for Mzee a law was introduced which made it illegal for any organisation or person to use the title president, except the head of state. The Cave Exploration Group of East Africa had to change its president to chairman. President's Pot at Thika, consequently had to be changed to Chairman's Pot. In December 1997 the ruling party KANU (The Kenya African National Union) finally got around to changing its constitution so that the head of state became the chairman rather than the president of the party.

The society has also prepared work for publication. Articles by members have appeared in journals such as the Shepton Mallet Caving Club Journal (Mills, 1980), the BCRA Bulletin (Simons, 1976b) and the NSS News (Simons, 1975b). Local publications have also featured some of our activities. The most extensive coverage being the first transit of Leviathan in 1976. This had received sponsorship from several local firms and they advertised in a supplement published in the Nation newspaper. We also have our own publications. The newsletter for members often has reviews and news of past trips and new discoveries. The Newsletter has changed format several times, between monthly, quarterly and, very occasional. Our Bulletin, renamed Speleophant in 1973, has become somewhat erratic. This is partly because of pressures of time also with the difficulties of outdated equipment. We have had to choose, in these economically testing times, between publishing and Leviathan. Leviathan won hands down. 
In these days of Desktop Publishing the standard of most caving publications have improved out of all recognition. However to use DTP you need access to the equipment that can run it. Until recently most of us have been stuck with out-dated, under-powered and incompatible equipment. This is partly a result of economic factors beyond our control. Import duties and taxes make new equipment prohibitively expensive. The computers that were being imported were often out of date equipment that was being replaced by the next generation in the developed world. As it could no longer be sold there, it was possible to dump such equipment here where it still had a market. Reconditioned 486 computers are currently available here for US\$700 plus VAT while a lower range new Pentium would cost at least twice as much. Cave Exploration Group of East Africa members have now managed to replace their CP/M machines and we intend to resume publishing Speleophant this year. We have reached a peak of fame of sorts. In January 1998 on Cartoon Network the famous Tazmania met a genie who set him three tasks, the third of which was to retrieve the famous ball of thread from the famous Leviathan Cave in Kenya. We expect an influx of juvenile cavers immediately.

We have also taken part in symposia. Our Chairman has represented us at previous meetings of the International Vulcanospeleological society. In 1974 The 4th International Bat Research Conference was held in Nairobi. We had a stand and Dieter Kock and Issa Aggundey presented papers (Hillman, A.K.K., 1975).

Cave biology has been a part of the Cave Exploration Group of East Africa interests, from the earliest days (Glover, 1966). We have a close relationship with the National Museum to whom we send species for identification. J. A. McFarlane published his work on the carnivorous beetles of Ithunda in the early 1970's (McFarlane, 1972). When the Hillman's were in Kenya and were active members of the Cave Exploration Group of East Africa there was a lot of work on cave biology. This was partly caused by the fact that Chris Hillman was working for his doctorate in biology. This resulted in the discovery of new species and of others that were identified in Kenya for the first time. The Hillman's also educated us in what was important for the study of cave biology, e.g. in which zone of the cave was the insect found, the temperature and relative humidity etc (Hillman, 1975). Thus a new species of pyrogoniscus lanceolotus was found and identified in 1977. As well as insects, we have also studied bats. The largest bat colony of Otomops martiensseni is found on Mt. Suswa and the extremely rare Hipposideros megalotis is also found (Kock et al. 1975). Fleas were found in Kiboko cave, which is rare in Kenya. Hillman also found a new cavernicole cockroach in Leviathan. Timberlake also explained what was needed in a bat survey (Timberlake, 1976).

One of the hazards that we face is that of finding animals in caves. The famous elephants of Mt. Elgon are probably the best known. Hyenas and leopards use caves as lairs. That is why you will find Cave Exploration Group of East Africa members making lots of noise before entering certain caves. It is not that they are trying to raise their spirits sufficiently to face the unknown darkness, rather they want any creature inside to come out or to roar to let us know that it is not safe to enter. Although this can be embarrassing, it is a lot safer than entering a narrow entrance to meet an angry leopard coming out. The first examination of a new cave in the Chyulu's was abandoned when it was noticed that lion tracks entered the cave but did not exit (Simons, 1975a, p.2). Other animals are also found in caves. The Cave Exploration Group of East Africa helped with the 1980 Operation Drake. This was a British project where groups of school children joined the round-the-world expedition for short periods of time. When the project was in Kenya Cave Exploration Group of East Africa members assisted in the exploration of Mt. Suswa caves while the army assisted with a bridge across the 
trench. In his account of the expedition,Lieutenant Colonel John Blashford-Snell, the leader of Operation Drake, describes a journey in one of the lava tubes on Mt. Suswa. While crawling along, he came to a chamber that had a small opening in the roof. In the pool of sunlight which this let in, lay a python sleeping soundly. The intrepid explorer and his companion tiptoed around the sleeping creature and proceeded to crawl along the next part of the tube. When this closed down, they retreated. On coming to the chamber they found that the python had woken up and taken off. They then had to exit the cave knowing that there was a python somewhere ahead of them. When being informed of this account our Chairman denies that this happened to Blashford-Snell, but in fact happened to two Cave Exploration Group of East Africa members. On another occasion Jim Simons reached out to grab a tempting tree root only to discover that it was a spitting cobra. Hence the name Cobra Cavern (Davies, 1974).

Besides subterranean hazards, we face problems of disease. Marbug's Fever has been mentioned, and hystoplasmosis is an enemy of all cavers, but malaria is also endemic in low-lying caving areas. Tick fever has also curtailed some expeditions.

Animals regularly fall into caves. This includes both domestic and wild animals (Hillman, 1975, Simons, 1982). In the early days of the Cave Exploration Group of East Africa, we were often invited to investigate fault caves into which animals had fallen. This was not a pleasant task as the atmosphere of decomposing animals was often overpowering. Bob Davis has a beautiful description of one such exploration, where the rift was actually as deep as it was rumoured to be (Davis, 1971). Animals falling into bat caves are often mummified by the dehydrating action of the guano. We have found many interesting specimens, ranging in size from civet cat to cow and kongoni. Mummies have been found in Suswa, Elmentaita and the Chyulu's (Simons, 1982).

The study of cave biology has also been linked to cave archaeology. Jim Simons did a lot of work on hyena and leopard lairs for Professor Glynn Isaac. The object of the study was to find what type of animals, scavengers took into the caves and what type of damage occurred to the bones. This was to help to identify which archaeological sites represented the homes of early hominids and which were of scavengers. It was also to study the differences between human and animal scavengers. This study involved collecting the bones from the hyena and leopard middens in the lava tubes and identifying and counting them (Simons, 1966).

Cave Exploration Group of East Africa members have been involved in other archaeological activities. Pottery shards have been discovered in the Tandala trench on the Chyulu's. These have been photographed and measured but have been left in situ so that they may be properly analysed at a later date (Soper, 1975). The rock cairns in Mathioni also in the Chyulu's have been left untouched but have been photographed and measured. These cairns are quite mysterious as their purpose is not yet known and they are deep within the dark part of the tube, which is very unusual for human artefacts in this country (Simons, 1972c). Simons has noted a cairn in Kimakia Cave also in the Chyulu's.

Cave Exploration Group of East Africa members have also been engaged in cave photography. Some of this has been in co-operation with professionals such as a Japanese television crew who filmed on Suswa with Dick Fordyce and Bill Tanner for a programme on the Rift Valley. Members have also made their own equipment. This has included filming with delayed flash release so as to paint the cave. The most home made effort involved the use of a car battery as a power point and aluminium foil covering a piece of cardboard as a reflector. This proved surprisingly effective and is another example of improvisation to compensate for lack of imported equipment.

All members of Cave Exploration Group of East Africa are active botanists. This is because while searching for entrances we have all learned to identify certain signs 
that a depression might be a collapse and then might be a cave entrance. If we see a fig tree (Ficus sp.) or a Dracaena sp. then we head in that direction and hope to hear the cries or "it goes".

The Cave Exploration Group of East Africa has always seen itself as a serious caving group. In 1965 we organised the first serious cave rescue group in Africa. If there was a problem in a cave all one had to do was to telephone the police who had the contact numbers of all the active cavers in the country and help would be on its way. This has fallen into disuse with the general decline of the national infrastructure. Frequently the police are unable to respond to emergency calls as their vehicles are grounded for lack of spare parts or fuel. In 1974 we practised a cave rescue on Mt. Suswa and were favourably impressed with our performance. Although the victim, who was nicely trussed up to simulate leg injuries, complained about rescuers knocking dust into her eyes.

When new techniques are developed we are also interested in learning. This even including a successful attempt at divining for caves using a forked stick (Watts, 1974). Lukenya, near Nairobi, and anybody's back garden that had a tree were favourite places for learning SRT. As we all know this gave massive grounds for hilarity even without trying to set records for prussiking up a tree. Cave diving was also introduced to East Africa (Davies, 1972). Gordon Davies introduced this in Lake Jipe and Cobra Cavern, but due to lack of backup this was never really followed up. Possibly because most other cave-divers fail to see the attraction of caving with crocodiles. Although the cave entrances on Mt. Suswa had been noticed from the air, and other entrances identified from aerial photographs of the Chyulu's, Gordon deliberately set out to be a sky caver. His pilot's licence was put to good use in over flights of the Chyulu Hills searching for surface holes that might give access to underground. Other members had also spotted apparent entrances while flying on wildlife surveys.

\section{CONCLUSION}

The Cave Exploration Group of East Africa has made a major contribution to vulcanospeleology in East Africa and the World. Despite limited resources and and being a mostly amateur group, i.e. none of the members are professionally involved in related fields such as geology, it has managed to push the boundaries of speleology in the region. This has been despite the socio-economic restrictions that are a fact of life in a developing country. CEGEA members have contributed a great deal to vulcanospeleology using their own resources in a hostile environment. Since the discovery of the great Leviathan system, CEGEA members have concentrated on this, almost to the exclusion of anything else. The region has an enormous potential given the amount of unexplored prospective cave area. The Cave Exploration Group of East Africa has never hesitated to welcome outsiders and to share its knowledge and to encourage others. With the proper resources, Kenya has the potential to contribute even more to vulcanospeleology.

\section{REFERENCES}

BERMAN, B. 1990. Control and Crisis in Colonial Kenya: The Dialectic of Domination, Nairobi. East African Educational Publishers

BRISTOW, C. 1961. The Mystery Caves of Elgon in East African Annual, 1960-61

CENTRAL BANK OF KENYA. 1991. Kenya: Land of Opportunity, Nairobi: Central Bank of Kenya

CHAKAVA, H. 1996. Publishing in Africa: One Man's Perspective, Nairobi. East African Educational Publishers 
CLARKE, R.J. 1996. Introductory Notes on the Use and Habitation of Caves by Man South of the Sahara. CEGEA Bulletin, Vol. 1, March, pp. 70-114.

DAVIES, G. 1972. Caves, Crabs and Crocodiles. CEGEA Bulletin, Vol. 3, pp. 10-12.

DAVIES, G. 1974. Scuba in Cobra. CEGEA Bulletin, Vol. 4, pp. 13-15.

DAVIS, B. 1971a. Recent Discoveries on Mt. Suswa. CEGEA Bulletin, Vol. 2, pp. 5-6.

DAVIS, B. 1971b. Kenya Rift Caves. CEGEA Bulletin, Vol. 2, pp. 30-34.

DAVIS, B. 1972. Elgon Adventure. CEGEA Bulletin, Vol. 3, 1 pp. 23-25.

GLOVER, P.E. 1965. First Presidential Address. CEGEA Newsletter No. 1, Feb. pp. 2-4.

GLOVER, P.E. 1966. A List of Plants Associated with the Lava Caves of Suswa Mountain. CEGEA Bulletin, Vol. 1, March, pp .28-50

HALLIDAY, W.R. 1975. Impressions of a Visiting American. CEGEA Bulletin, Vol. 5, pp. 25-27.

HILLMAN, A.K.K. 1975. The Fourth International Bat Research Conference, Nairobi September 1975. CEGEA Bulletin, Vol. 5, pp. 28-29.

HILlMAN, C. 1973. East African Cave Fauna and Flora. CEGEA Bulletin, Vol. 3, p.14.

HILlMAN, C. 1975. Tandala Trench: an Open Lava Tube in the Chyulus. CEGEA Bulletin, Vol. 5, 1975, pp. 9-13.

KARIMI, J. and P. OCHIENG. 1980. The Kenyatta Succession, Nairobi, Transafrica Distributers.

KING, C. 1971. Original Exploration of Cave 6A. CEGEA Bulletin, Vol. 2, pp.6-7.

KOCK, D., J.C. HILLMAN and A.K.K. HILLMAN. 1975. A Colony of a Rare Bat Discovered. CEGEA Bulletin, Vol. 5, pp. 30-31.

LEYS, C. 1994. Underdevelopment in Kenya, Nairobi. East African Educational Publishers

MASON, E.I. 1965. Construction and Use of the Group's Ladders. CEGEA Newsletter No. 1, Feb. pp. 35-37.

MCFARLANE, J.A. 1971. The Carnivorous Beetles of the Ithunda Caves, Kenya. Studies in Speleology, Vol 2 (for 1970-71), pp. 149-158.

MILLS, M.T. 1980. An Outline History of Vulcanospeleology. Journal of the Shepton Mallet Caving Club, Series 6, No. 10, Autumn, pp. 13-26.

MWANIKI, H.S.K. 1973. The Living History of Embu and Mbeere, Nairobi: Kenya Literature Bureau

NYAMWERU, C. 1980. Rifts and Volcanoes, Nairobi. Thomas Nelson

OGONDA, R.T. 1992. Kenya's Industrial Progress in the Post-Independence Era: An Overview of Kenya's Industrial Performance up to 1980. OCHIENG, W.R. and R.M. MAXON. An Economic History of Kenya, Nairobi: East African Educational Publishers, pp. 297-311.

ORWA, D.K. 1994. Continuity and Change: Kenya's Foreign Policy from Kenyatta to Moi. OYUGI, W.O. Politics and Administration in East Africa. Nairobi. East African Educational Publishers. pp. 297-330.

PRESTON, R. 1995. The Hot Zone, London: Corgi

SIMONS, J.W. 1966. The Presence of Leopard and a Study of the Food Debris in the Leopard Lairs of the Mount Suswa Caves, Kenya. CEGEA Bulletin, Vol. 1, pp. 51-69.

SIMONS, J.W. 1969. The Rediscovery of the Cave of God. CEGEA Newsletter No. 5, June, pp. 10-12.

SIMONS, J.W. 1971. New Caves in the Chyulu Hills, Kenya. CEGEA Bulletin, Vol. 2, pp.33-38.

SIMONS, J.W. 1972a. Notes on a Lava Tunnel on Nyamulagira Volcano, Zaire. CEGEA Bulletin, Vol. 3, pp. 19-21.

SIMONS, J.W. 1972b. More Collapse Holes and Caves in the Chyulu Hills, Kenya. CEGEA Bulletin, Vol. 3, pp.29-34.

SIMONS, J.W. 1972c. The Mathioni Series, North Chyulu Hills, Kiboko, Kenya. CEGEA Bulletin, Vol. 3, pp. 40-50.

SIMONS, J.W. 1974. Yet More Caves on Suswa Main Flow. CEGEA Bulletin, Vol. 4, pp. 2-6.

SIMONS, J.W. 1975a. Lava Caves in the Virunga Mountains in NSS News, Vol. 33, No. 10, Oct, p.163.

SIMONS, J.W. 1975b. Notes on New Lava Tubes in the Chyulu Hills. CEGEA Bulletin, Vol. 5, pp. 2-5.

SIMONS, J.W. 1979. Extending the Suswa Main Flow Caves. CEGEA Newsletter, No. 1, Jan-Mar, pp. 3-6.

SIMONS, J.W. 1982. Kenya Cave Mummies. CEGEA Bulletin, Vol. 6, pp. 32-37.

SIMONS, J.W. 1976. Leviathan Cave - A Major Lava Tube in Kenya in BCRA Bulletin No. 14, Nov. pp. 23-25.

SIMONS, J.W. 1998. Volcanic Caves of Kenya, Nairobi. privately published.

SOPER, R. 1975. Pottery Sites in Tandala Trench, Chyulu Hills. CEGEA Bulletin, Vol. 5, pp. 15-16.

THOMSON, J. 1885. Journey Through Masailand, London

THROUP, D. AND C. HORNSBY. 1998. Multiparty Politics in Kenya, Nairobi. East African Educational Publishers.

TIMBERLAKE, J. 1977. Bat Survey. CEGEA Newsletter, Nos. 3\&4, July-Dec, pp. 6-9.

WATTS, C. 1974. Cave Divining - Suswa. CEGEA Bulletin, Vol. 4, pp. 1-2.

WOMACK, D. 1998. Saturday Night, Sunday Morning. CEGEA Bulletin, forthcoming.

WORLD BANK. 1995. World Development Report 1995, New York. Oxford University Press. 